\title{
Penciptaan Konserto Etude Tangganada Pentatonik untuk Pembelajaran Violin dan Orkestra
}

\author{
Pipin Garibaldi ${ }^{1}$ dan Brian Farant \\ Prodi Seni Musik, Fakultas Seni Pertunjukan, Institut Seni Indonesia Yogyakarta
}

\begin{abstract}
The Creation of Pentatonic Scale Etude Concerto for Violin and Orchestral Learning. This research aims to explain creating a musical work in the form of a violin etude in the form of a concerto. The concerto is arranged in a free pentatonic scale from traditional Javanese idioms: the lancaran and gangsaran rhythm. The concerto consists of one movement that contains etude material, namely learning the technique of playing the violin in a beautiful and exciting melody. The problem highlighted is students' difficulty learning etude for the violin, which is often considered complicated. In the learning process, students tend to be oriented towards violin music such as concertos, sonatas, or musical pieces (short works) compared to etude works. Therefore, it is important for creating the concerto etude to bridge the students' violin learning process, both for educative and performative dimensions. Creating the etude concerto in this traditional idiom is expected to foster student interest in learning to practice etude. The research was organized in several stages: document collection, observation, artistic, trial, and dissemination. The research/design method was taken from Reginald Smith Brindle (1986), i.e., Musical Composition and King Palmer Teach Yourself to Composed Music (1952). The method is as follows: listening to different music that is close to the research topic to find ideas, using the violin and piano to make melodic pieces, including double, triple, four-stop techniques, connecting, combining, developing synchronized melody pieces, rhythmic variations, rhythms, articulation variations, syncopations, rhythm figures, melodic decorations, harmonies, dynamic variations, and so on. The conclusion of the research on creating a concerto with one movement is more freedom to express ideas. The use of lancaran and gangsaran rhythms in a pentatonic scale to give the nuances of the Central Java region, turns out to be more nuanced with a Mandarin concerto. After being implemented, it turns out that this concerto is still quite difficult for learning violin 3 .
\end{abstract}

Keywords: concerto; etude; violin; pentatonic

\begin{abstract}
ABSTRAK
Penelitian ini bertujuan untuk menjelaskan proses penciptaan karya musik berupa etude biola dalam bentuk konserto. Konserto disusun dalam tangga nada pentatonik bebas yang bersumber dari idiom tradisi jawa, yakni ritme lancaran dan gangsaran. Konserto terdiri dari satu gerakan yang mengandung materi etude, yaitu pembelajaran teknik permainan biola dalam melodi yang indah dan menarik. Permasalahan yang disoroti yaitu kesulitan mahasiswa dalam mempelajari etude untuk biola yang kerap kali dianggap sukar ataupun rumit. Dalam proses pembelajaran, mahasiswa cenderung berorientasi pada karya musik biola seperti konserto, sonata, ataupun buah musik (karya pendek) dibandingkan dengan karya etude. Penciptaan konserto etude penting dilakukan guna menjembatani proses pembelajaran biola mahasiswa baik dalam dimensi edukatif maupun performatif. Kreasi konserto etude dalam idiom tradisi ini diharapkan dapat menumbuhkan minat belajar mahasiswa untuk berlatih etude. Penelitian disusun dalam beberapa tahap yaitu: pengumpulan dokumen, observasi, artistik, uji coba, dan diseminasi. Metode penelitian/perancangan diambil dari Reginald Smith Brindle (1986), Musical Composition dan King Palmer Teach Yourself to Composed Music (1952), yaitu mendengarkan berbagai musik yang dekat dengan topik penelitian untuk mencari ide, memakai biola dan piano untuk membuat potongan-potongan melodi termasuk teknik double, triple, four stop, menyambung, menggabungkan, mengembangkan mesinkronisasi potongan-potongan
\end{abstract}

$1 \quad$ Alamat korespondensi: Program Studi Pendidikan Musik, Fakultas Seni Pertunjukan, Institut Seni Indonesia Yogyakarta. Jalan Parangtritis Km. 6.5 Yogyakarta. E-mail: pipingaribaldi@gmail.com; HP.: 08122961388. 
melodi, variasi melodi, ritme, variasi artikulasi, sinkopasi, figur ritme, dekorasi melodi, harmoni, varasi dinamik dan seterusnya. Kesimpulan penelitian penciptaan konserto dengan satu gerakan lebih leluasa untuk menuangkan ide. Pemakaian irama lancaran, dan gangsaran dalam tangganada pentatonik supaya bernuansa daerah Jawa Tengah, ternyata lebih bernuansa konserto Mandarin. Setelah diterapkan ternyata konserto ini masih cukup sulit bagi pembelajaran violin 3 .

Kata kunci: konserto; etude; biola; pentatonik

\section{Pendahuluan}

Konserto berasal dari bahasa Latin concertare, yang berarti melawan, menentang, berjuang, perselisihan, dan perdebatan. Pertama diketahui penerapan secara musikal pada un concerto di voci in musica di Roma tahun 1519, yang mengacu pada ansambel vokal, ialah menyatukan atau mengumpulkan suara-suara (a getting together of voices). Publikasi paling awal dalam nama konserto adalah Concerti di Andrea, et di Gio karya Gabrieli yang berisi musik gereja dan madrigal dalam enambelas bagian. Sepanjang pertengahan pertama abad ketujuh belas, konserto merupakan istilah umum untuk musik-musik vokal dari Itali yang diiringi instrumen, dipakai khusus untuk musik gereja. Pada abad ketujuh belas concerto dan concertato digunakan semata-mata untuk menggambarkan musik instrumental (Sadie, 2002).

Karya-karya terdahulu yang memberikan ciriciri konserto instrumental adalah sonata-sonata dan sinfonia, ditulis untuk pembagian orkestra yang terdiri dari konserto grosso (kelompok besar) dan konsertino (kelompok kecil) (Stein, 1962). Pada periode ini konserto grosso dari Corelli menjadi model terkenal, dan menunjukkan ciri pokok konserto Venetia bentuk tiga bagian, cepatlambat-cepat, bentuk ritornello dan solo virtuoso (McNeill, 1998).

Konserto-konserto Corelli secara esensi adalah perluasan dari Corellian sonata, dengan tutti orkestra dipakai untuk menyela kadens, atau kelompok solo untuk menggemakan tutti. Adapun konserto pada Torelli dimaksudkan untuk pertunjukan orkestra, dengan satu instrumen sebagai pemain solo, bukan seperti dalam konserto grosso (Sadie, 2002). Komposer yang paling berpengaruh pada sejarah konserto barok adalah Vivaldi, yang pertama mengembangkan secara penuh bentuk dan gaya dari model Torelli.

Perkembangan konserto dari Barok ke Klasik dilanjutkan oleh anak-anak dari J.S. Bach, dan komposer konserto sejamannya seperti Stamitz, Sammartini, Pugnani, Boccherini (Itali), Joseph dan Michael Haydn, Dittersdorf, Wagenseil (Jerman). Pada konserto klasik terdapat modulasi setelah ritornello dalam dominan, hampir sama dengan perkembangan dalam bentuk sonata, dan rekapitulasi lengkap berisi meteri-materi tema yang sudah dihadirkan (Stein, 1962). Puncak kesempurnaan konserto klasik berada pada Mozart dan Beethoven. Mozart membuat lima konserto biola yang menunjukkan sejumlah pengaruh dari konserto biola Italia dan serenade Austria, dengan menggabungkan melodi-melodi rakyat dalam bentuk minuet dan rondo. Semua konserto Mozart lebih mengutamakan ekspresi keindahan dan melodi dibanding sekedar memamerkan teknik. Konserto pada Beethoven masih menunjukkan prinsip-prinsip klasik tetapi dengan penggarapan yang lebih luas, baik pada ritornello (eksposisi ganda), tema pertama dan kedua, perkembangan, dan bahkan bagian koda menjadi lebih panjang (Sadie, 2002).

Konserto romantik awal terdapat pada karya-karya Viotti no. 22 dalam A minor, dan 12 konserto dari Spohr, dimana rasa warna dan melodi romantik dikembangkan secara penuh. Akan tetapi konserto biola yang sangat luar biasa adalah karya Mendelsohn dalam E minor op. 64 dimana solis masuk langsung menyanyi pada tema dengan lembut. Bentuk konserto yang telah dibangun oleh Mendelsohn, diikuti pula oleh komposer Saint-Saens dan Max Bruch. Adapun 
konserto biola dari Schumann, hanya sedikit menunjukkan kejeniusannya, sangat tipis isinya tetapi tidak dangkal pasase-pasasenya (Cole, 1979). Virtuoso konserto pada jaman Romantik muncul pada Paganini, yang membawa konsep virtuoso romantik kepuncak baru, mempesona, menakjubkan, dan belum pernah ada sebelumnya, sampai mendapat sebutan gaya setan. Perkembangan konserto selanjutnya sampai dengan adanya istilah konserto gaya simfoni dengan komposer J. Brahms, dimana konserto pianonya yang pertama sebetulnya dimaksudkan untuk karya simfoni. Jadi meskipun bagian solo dan orkestra sangat luar biasa, tetapi karakter musiknya tetap seperti karya simfoni. Demikian pula dengan konserto biolanya yang sangat terkenal, bergaya konserto simfoni. Konserto-konserto biola favorit romantik akhir di antaranya adalah karya Lalo Symphonie Espagnole op. 21, yang terdiri dari lima bagian, Tchaikovsky konserto dalam D op. 35, karya yang sangat kuat dan bersemangat, Dvorak konserto op. 53, yang memunculkan tema Slavonic, dan musik rakyat Cekoslovakia, kemudian pemain biola Polandia Wieniawsky, yang menggabungkan melodi liris dengan teknik yang sangat sulit (Sadie, 2002).

Pada konserto klasik dan romantik dapat didefinisikan bahwa konserto adalah sebuah karya untuk solo instrumen atau sekelompok solo instrumen dengan iringan orkestra, yang mempertahankan kontras diantara solo atau sekelompok instrumen dengan kelompok besar (orkestra), ditujukan terutama untuk menekankan permainan idividu solo instrumen dan untuk memamerkan kehebatan teknik pemain. Konserto biasanya terdiri dari tiga bagian disertai dengan sebuah kadensa, dimana pemain diberi kesempatan untuk mendemonstrasikan kehebatannya tanpa diiringi dengan orkestra Bagian kedua bertempo lambat, berkarakter liris atau sangat bergairah, melodius, dengan memakai bentuk lagu (song form) atau menggunakan bentuk tema dan variasi. Bagian ketiga pada karya konserto seringkali menggunakan bentuk rondo, dengan karakter lincah dan bersemangat (Machlis, 1963).

Pada abad ke-20 perlakuan terhadap konserto romantik konvensional lebih bebas, baik pada bentuk maupun hubungan antara solis dengan orkestra, hal ini terdapat di dalam konserto Rakhmaninov, Walton, Shostakovich, dan Prokoviev. Konserto-konserto abad ke-20 banyak yang dibuat karena pesanan dari pemain-pemain hebat, sehingga menghasilkan karya-karya yang sukar dan lebih mengutamakan virtuoso teknik dibanding kualitas musikal, seperti konserto biola dari Schoenberg dan Alban Berg. Schoenberg dan Berg menulis konserto biola dengan metoda serial duabelas nada. Akan tetapi Stravinsky, Hindemith dan beberapa pengikut neo klasik, cenderung mengambil perubahan yang lebih radikal, seperti memakai bentuk suita barok dengan musik yang selalu berubah dan diisi kontrapung dissonan. Konserto biola Stravinsky adalah seperti konserto barok dalam konsep bentuk dan poliponi. Model seperti ini juga dilakukan oleh Hindemith, Kodaly, dan Bartok.

Etude adalah studi atau latihan untuk menguasai teknik tangan kiri dan tangan kanan. Dalam berlatih teknik yang diutamakan ialah nilai manfaat, bukan masalah artistik atau rasa musikal, meskipun terdapat etude musikal seperti 24 caprice dari Rode dan Paganini. Pada instrumen piano, dengan 27 etude piano yang dibuat oleh Frederic Chopin, etude menjadi sebuah komposisi musik yang amat menarik, dan terlepas dari esensinya sebagai studi yang bersifat teknis. (Westrup et al., 1976).

Etude atau studi tentang teknik yang sering pula disebut dengan caprice, adalah sebuah sebuah komposisi pendek yang bebas, pada umumnya kurang mengandung nilai musikal. Oleh karena itu etude tidak untuk pertunjukan pada publik, tetapi secara pokok bertujuan untuk memperluas kemampuan teknik pemain. Dengan terpublikasikannya 24 Caprice karya Paganini, komposisi etude membawa ke dalam suatu petunjuk baru, dimana etude menjadi karya paling bernilai dalam pengembangan teknik biola, dan membuat para pemain biola sangat mengapresiasi pengembangan karya Paganini dalam komposisi. Dalam tahun 1870 an, Jacob Dont, mempublikasikan karya-karya untuk studi teknik, yang dapat disejajarkan dengan karyakarya dari Kreutzer dan Rode. Jacob Dont adalah juga pendidik yang mencoba membebaskan 
pengetahuan penjarian, dari cara-cara lama ke cara baru.

Tangganada pentatonik (terdiri dari lima nada) telah digunakan sejak bangunan piramid didirikan, menurut penemuan para ahli arkeologi dan penelitian ahli musikologi dari gambar-gambar flute, harpa, dan pemain lute, dan masih dipakai sampai sekarang. Ciri-ciri penting dari tangganada pentatonik adalah tidak adanya nada dengan jarak setengah. Berikut adalah notasi tangga nada pentonik.

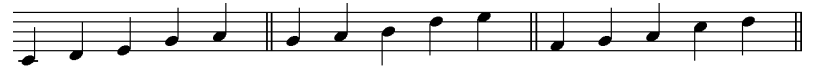

Gambar 1: Tangganada pentatonik.

Dengan tidak adanya jarak setengah maka mempunyai dua efek, pertama, tidak ada nada leading note (nada yang minta penyelesaian ke tonika), tidak ada tension jarak setengah sehingga membuat pentatonik lebih konsonan (tidak tajam). Kedua, tidak memungkinkan membentuk akor dominan, harmoni sedikit statis, tidak memerlukan penyelesaian tegas atau kadens yang kuat (Brindle, 1986).

Tangganada pentatonik sangat umum dan dapat ditemukan di seluruh dunia, termasuk di dalam musik rakyat Celtik, musik rakyat Hongaria, musik Afrika Barat, African-American spirituals, musik jazz, musik blues dan rock Amerika, musik tradisional Yunani, musik Albani Selatan, musik gamelan Indonesia, musik kulintang Philipina, melodi-melodi musik rakyat dari Korea, Jepang, China, India, tradisi Afro-Carabia, dan komposerkomposer klasik Barat seperti Claude Debussy dari Perancis.

Bidang Etnomusikologi secara umum mengklasifikasikan tangganada pentatonik baik sebagai hemitonik ataupun anhemitonik. Hemitonik tangganada seprti minor, sedangkan anhemitonik semacam tangganada mayor yaitu: C-D-E-G-A-C (Sadie, 2002). Berikut adalah notasi tangga nada anhemitonik.

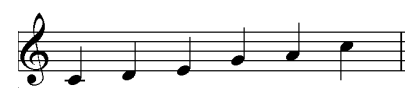

Gambar 2: Tangganada anhemitonik.

Hemitonik boleh jadi disebut minor, tetapi istilah yang paling umum dipakai adalah relatif minor pentatonik yang berasal dari pentatonik mayor. Tangganada A minor pentatonik yaitu relatif minor dari $\mathrm{C}$ mayor, akan dimulai dari $\mathrm{A}$ menjadi A-C-D-E-G-A. Berikut adalah notasi tangga nada hemitonik.

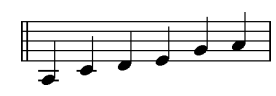

Gambar 3: Tangganada hemitonik.

Menurut Dieter Mack, tangganada pentatonik anhemitonik tidak asing dalam sejarah musik Barat, terutama pada lagu-lagu Gregrorian. Yang unik di Indonesia bahwa konsep pentatonik dapat dikembangkan dan divariasikan, di Barat pentatonik berdasarkan jarak interval yang sudah distandarisasi, sedangkan di Indonesia keselarasan tanpa standar interval tertentu. Dari segi melodi keselarasan di Indonesia jauh lebih kaya dan rinci dibandingkan dengan melodi Barat, dan untuk laras pelog serta variasinya sama sekali tidak ada di Barat (Mack, 1995).

Berdasarkan definisi konserto tersebut di atas, yaitu merupakan karya untuk solo instrumen dengan iringan orkestra, yang menekankan permainan idividu untuk memamerkan kehebatan teknik pemain, demikian pula berdasarkan definisi etude yaitu studi tentang teknik, dimana etude sangat penting untuk mengembangkan keterampilan tangan kiri maupun kanan, maka dibuatlah rancangan Konserto Etude untuk Biola dan Orkestra dalam Tangganada Pentatonik Bebas. Alasan lainnya adalah, bahwa pelajar biola baik non formal (murid-murid les privat) maupun formal (mahasiswa Jurusan Musik) kurang suka belajar etude (teknik), selain sukar juga kurang menarik, karena kurang mengandung nilai-nilai keindahan. Adapun pemakaian tangganada pentatonik, adalah untuk mengekspresikan warna lokal atau daerah, yaitu irama lancaran dan gangsaran dari Jawa.

Konserto etude ini tidak seperti konserto pada umumnya yang terdiri dari tiga gerakan, tetapi hanya ada satu gerakan saja yang berisi unsur cepat-lambat- cepat, dengan kadensa di dalamnya. Adapun tangganada yang dipakai adalah pentatonik bebas, mengingat semua instrumen barat sudah distandarisasi pitch nya, sedangkan instrumen daerah seperti gamelan umumnya berdasarkan rasa sipembuat gamelan. Berdasarkan hal ini, maka rumusan penciptaan, ialah sebagai 
berikut: (1) Bagaimana menciptakan konserto biola dalam bentuk bebas, dalam satu gerakan, yang berisi unsur konserto cepat-lambat-cepat; (2) Bagaimana menciptakan konserto biola yang sekaligus berisi etude atau teknik-teknik biola?; (3) Dapatkah ritme atau irama lancaran dan gangsaran, dalam pentatonik bebas (anhemitonik) dipakai sebagai pendukung karya yang lebih bernuansa Timur (Jawa) dibanding suasana Barat?

Adapun tujuan penciptaan konserto adalah untuk menghasilkan konserto biola dalam satu gerakan, berisi etude atau pembelajaran teknik-teknik biola dalam melodi-melodi yang indah dan menarik, memakai suasana daerah dengan irama atau ritme lancaran dan gangsaran, dalam tangganada pentatonik, sehingga pelajar biola akan menjadi suka belajar etude meski sesungguhnya sukar.

\section{Metode Penelitian}

Di dalam bidang penciptan musik ada yang berpendapat bahwa komposisi tidak dapat diajarkan dan seharusnya tidak diajarkan, komposer dianggap sebagai orang yang memang terlahir sebagai komposer. Akan tetapi bagi yang sedang belajar komposisi, mempunyai portofolio menonjol pada komposisi, mempunyai instink untuk menulis komposisi, tetap disarankan mempelajari berbagai partitur musik, dicari bagaimana, mengapa musik itu dibuat, sehingga dapat memakai teknik-teknik yang mereka gunakan di dalam membuat karya sendiri. Berbagai macam musik yang didengar dan dipelajari akan memberikan banyak ide, dan guruguru komposisi adalah sebatas pemberi informasi, pendorong semangat, untuk terus berkreasi, tanpa menonjolkan keilmuannya, memaksakan keinginannya, mengkritik dengan cara yang menghancurkan (Brindle, 1986).

Brindle memberikan metode dengan menuliskan, mencoret-coret potongan melodi, akorakor, atau apa saja, sebagai ide pertama. Dengan terus berkreasi (mencipta) pikiran akan mulai terbangkitkan ide-ide yang tidak bergerak maju terus. Adapun Palmer menawarkan tiga metode di dalam penciptaan komposisi berdasarkan yang telah dilakukan oleh komposer-komposer besar, ialah: (1) Pemakain instrumen piano sebagai alat bantu untuk mencari ide, dilakukan oleh Rimsky-Korsakoff dan murid-muridnya; (2) Membawa buku catatan, dengan selalu menuliskan potongan-potongan melodi ide-ide yang muncul dimana dan kapan saja. Beethoven selalu membawa buku catatan untuk membantu memorinya; (3) Mendengarkan musik dari komposer lain. Cesar Franck memainkan karya Wagner pada piano untuk membangkitkan idenya, misal jika ingin mencipta Waltz maka banyak mendengarkan karya-karya waltz, bukan mendengarkan bagian lambat dari sebuah simfoni (Palmer, 1952).

Berdasarkan uraian metode perancangan dari metode penciptaan Reginald Smith Brindle (1986) Musical Composition, dan King Palmer Teach Yourself to Composed Music (1952), maka peracangan ini dilakukan langkah-langkah sebagai berikut, yaitu: (1) Mendengarkan berbagai musik untuk mendapatkan ide, yaitu musik yang dekat dengan musik yang akan dibuat (Brindle, 1986). Dalam hal ini mendengarkan konserto-konserto dalam tangganada pentatonik, mendengarkan musik karawitan dalam irama lancaran dan gangsaran; (2) Memakai instrumen biola dan piano untuk mendapatkan potongan-potongan melodi (termasuk teknik double, triple, dan four-stop) dan harmoni, kemudian menuliskannya (Palmer, 1952); (3) Menyambung, menggabungkan, mesinkronisasi potongan-potongan melodi, mengembangkan melodi, membuat variasi melodi, ritme, variasi artikulasi, sinkopasi, figur ritme, dekorasi melodi, harmoni, varasi dinamik dan seterusnya; (4) Selesai karya pokok untuk biola, kemudian membuat iringan untuk orkestra, yaitu membuat orkestrasi dari instrumen gesek, tiup, perkusi, register suara, penggabungan semua dua, tiga suara, sampai dengan full orchestra (Adler, 2002).

Proses penciptaan pertama, dimulai dengan memastikan tanggananada pentatonik anhemitonik yang akan digunakan, kemudian menyusun menjadi suatu harmoni berdasarakan urutan tangganada tersebut. Berikut adalah susunan harmoni berdasarkan tangganada pentatonik anhemitonik.

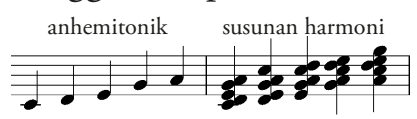

Gambar 4: Susunan harmoni berdasarkan tangganada pentatonik anhemitonik. 
Kedua, mendengarkan beberapa gending karawitan seperti bentuk gending lancaran, ketawang, ladrang, gangsaran, dan juga mendengarkan gaya permainan rebab Jawa, gaya sindenan baik laki-laki maupun perempuan, serta gaya sahutsahutan antara sinden perempuan dan laki-laki.

Ketiga, memastikan mengambil melodi irama lancaran dan ritme gangsaran menjadi dasar utama dari komposisi. Berikut adalah notasi melodi irama lancaran dan ritme gangsaran.

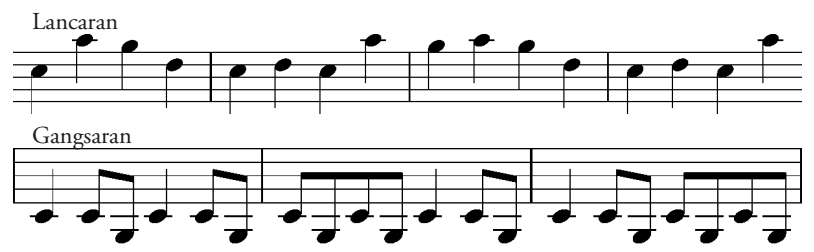

Gambar 5: Melodi irama lancaran dan ritme gangsaran.

Keempat, memastikan etude atau studi teknik yang dipakai, teknik tangan kiri ialah tangganada mayor tiga oktaf, arpeggio, double-stop, triple-stop, glisando, four-stop, finger exercise gaya Schradieck, dan teknik tangan kanan ialah detache, legato, spiccato, atau legato spiccato. Berikut adalah notasi tangga nada tiga oktaf, arpeggio, double-stop, triplestop, four-stop, finger exercise, glisando, spiccato.

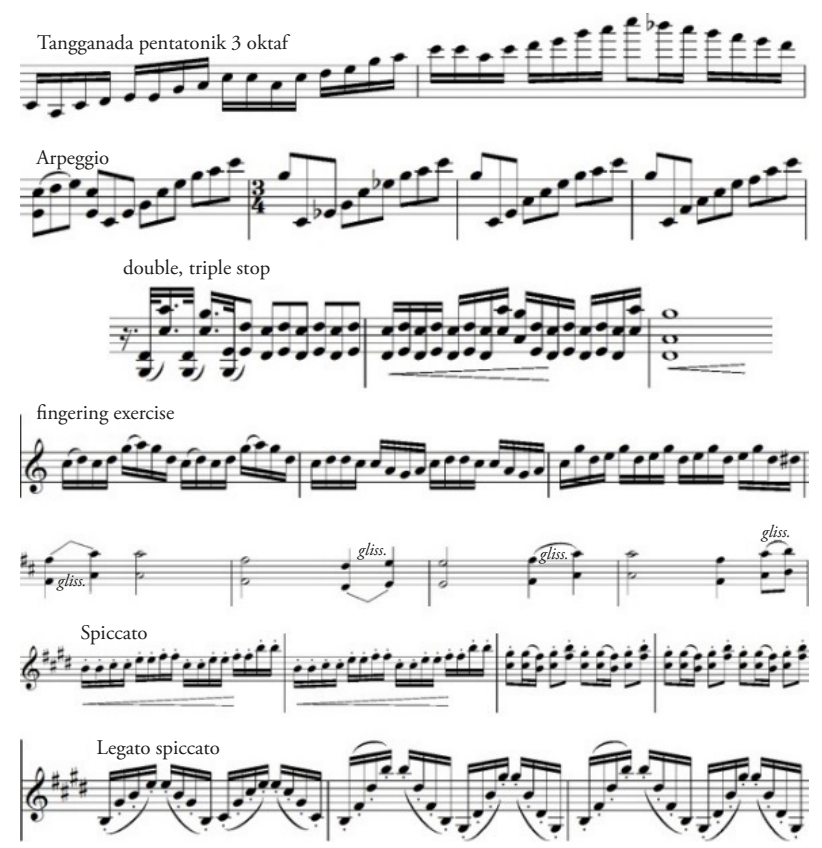

Gambar 6: Tangga nada tiga oktaf, arpeggio, doublestop, triple-stop, four-stop, finger exercise, glisando, spiccato.

Penciptaan karya konserto biola sudah sangat banyak, dengan berbagai maksud dan tujuan sesuai dengan kehendak komposer atau keiinginan pemain biola itu sendiri. Oleh karena itu dalam penelitian ini perlu ditinjau beberapa karya yang dapat dipaparkan yang cukup dekat dengan penciptaan ini ialah sebagai berikut.

The Butterfly Lovers Concerto for Violin and Orchestra (Violin Concerto Liang Shanbo dan Zhu Yingtai) karya Chen Gang dan HeZhan Hao, dibuat pada tahun 1958-59, adalah konserto biola dalam satu gerakan, berisi tiga seksi yaitu cepat-lambatcepat, menggunakan idiom-idom permainan Erhu seperti teknik glisando, portamento, pergeseran vibrato yang ekspresif, dengan durasi 25 menit. Selanjutnya konserto direvisi dalam gaya opera Cina tentang cerita Butterfy Lovers yaitu percintaan antara Liang Shanbo dan Zhu Yingtai seperti cerita Rome dan Yuliet. Karya ini dimainkan pertamakali tahun 1959 di Shanghai Lyceum Theatre, oleh Shanghai Concervatory Shymphony Orchestra, kondakter Fan Chengwu, dan solois Yu Lina. Kemudian dimainkan oleh New York Philharmonic, 9 Februari 2016, dengan kondakter Long Yu, solois Maxim Vengerov (Keller, 2016).

Konserto Oboe dengan Keroncong dan Orkestra Sebuah Konsep Komposisi Baru untuk Musik Keroncong, karya Singgih Sanjaya. Karya ini terdiri dari dua gerakan yaitu Allegro Spirituoso untuk gerakan pertama, dan Lento sebagai gerakan kedua. Komposisi ini dipergelarkan di Solo International Keroncong Festival, di Ngarsopuro Solo, tahun 2012, oleh Keroncong Light Orchestra, yang didirikan oleh Singgih Sanjaya. Komposisi ini diadaptasi dan dikembangkan dari konserto klarinet dengan keroncong dan orkestra, yang dipergelarkan di Taman Budaya Yogyakarta tahun 2009. Keroncong yang aslinya adalah musik hiburan dan terdiri dari vokal, flut, biola, gitar, cuk, cak, celo, bass, diangkat ke dalam karya konserto dengan merubah instrumentasi, tangganada, harmoni, dan tanda sukat. Instrumen orkestra yang dipakai ialah 2 flute, oboe, horn, trumpet, trombone, chimes, xylophone, biola 1 dan 2, alto, celo, bass. Harmoni keroncong yang sederhana diperluas dengan diminis, augmented, hingga atonal. Pemakaian tanda sukat 4/4 dari keroncong, di dalam konserto menjadi tidak terbatas yaitu memakai multi meter atau multi time signature. 
Fantasia in Pentatonic Scale for Alto Saxophone and Orchestra karya Budhi Ngurah tahun 1998, merupakan sebuah karya satu gerakan yang di dalamnya berisi beberapa seksi yang ditandai dengan tanda tempo. Seksi pertama dalam tempo Largo, quasi meditativo, kedua dalam tempo Allegro, ketiga dalam tempo Largo yang disisipi tempo Andante 8 birama, keempat tempo Moderato, kelima tempo Allegro, dan ditutup dengan Andante pada tiga birama terakhir. Fantasia adalah suatu karya musik dengan bentuk bebas, tidak se-perti bentuk sonata, rondo, variasi dan sebagainya. Komposisi ini dibuat dalam tangganada pentatonik yaitu pentatonik pelog dengan unsurunsur Bali, atau dapat dikatakan mengolah idiom tradisi Indonesia yaitu gamelan Bali memakai cara atau metode musik Barat. Fantasia ini juga sama seperti konserto karena memakai instrumen solo saxophone dengan iringan orkestra, dan meskipun memakai tangganada pentatonik, tetapi dibuat dengan harmoni modern, pola ritme yang rumit, banyak pergantian sukat, dan juga pergantian tempo.

\section{Hasil dan Pembahasan}

Rancangan konserto etude untuk biola dan orkestra dimulai dengan membuat komposisi untuk solo biola, berdasarkan ide yang telah diuraikan dalam latar belakang, tujuan perancangan, proses penciptaan, dan seterusnya, dengan memainkan biola untuk mendapatkan motif pertama sebagai pembuka untuk solo biola dalam teknik doublestop, triple-stop, dan four-stop. Ketiga teknik permainan biola ini tergolong dalam variasi dari multiple-stops yang lazim ditemukan pada repertoar musik biola dari tingkat menengah hingga tingkat lanjut. Secara prosedural, teknik ini dapat dipahami dengan cara membunyikan dua nada ataupun lebih pada waktu yang sama dengan pola pergerakan jari secara diagonal (de Fretes et al., n.d.). Berikut adalah motif pertama sebagai pembuka biola solo dalam teknik double-stop, triple-stop dan four-stop.

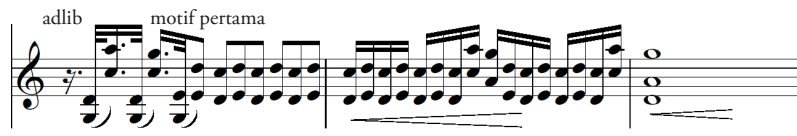

Gambar 7: Motif pertama sebagai pembuka biola solo.
Setelah motif pertama sebagai pembuka, selanjutnya dirancang sebuah tema utama dari karya ini, akan tetapi bukan tema utama seperti dalam sonata form karena ini dalam bentuk bebas, untuk belajar double-stop dan arpeggio seperti dalam Carl Flesch Scale System. Berikut adalah notasi tema utama konserto.

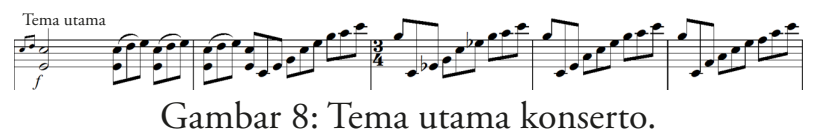

Berikutnya dibuat suatu teknik latihan penjarian, gesekan dua legato dua detache, seperti etude dalam buku Sevcick atau Schradick. Berikut adalah notasi untuk latihan teknik penjarian yaitu gesekan dua legato dan dua detache.

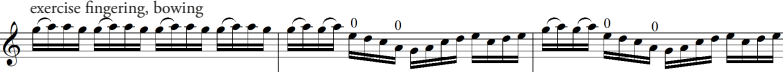

Gambar 9: Teknik latihan penjarian, gesekan dua legato dan dua detache.

Selanjutnya dibuat suatu teknik untuk belajar acciacatura dan glisando portamento, yang diadaptasi dari permainan rebab Jawa. Berikut adalah teknik acciacatura dan glisando portamento.

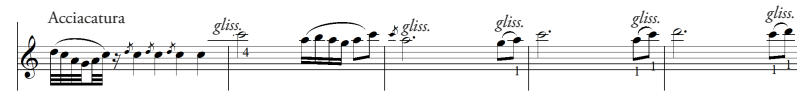
Gambar 10: Teknik acciacatura dan glisando portamento.

Berikutnya dirancang teknik untuk belajar triple-stop, double-stop, glissando, dan portamento memakai ritme gangsaran dalam permainan karawitan Jawa. Berikut adalah teknik untuk belajar triple-stop, double-stop, glissando, dan portamento.

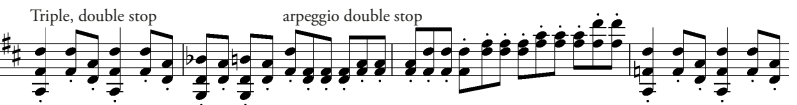

Gambar 11: Teknik untuk belajar triple-stop, doublestop glissando portamento.

Seperti pada umumnya sebuah konserto, maka pada karya ini juga dirancang sebuah kadensa untuk menunjukkan keterampilan solis biola, dan tentu saja berisi dari berbagi teknik. Menurut Rosiana Dewi, kadensa memberikan peluang bagi solis untuk menunjukkan kepiawaian dari aspek teknis yang terdapat dalam tradisi konserto. Meskipun kadensa mengandung variasi tema dan terkesan penuh improvisasi dari solis, kadensa pada umumnya ditulis oleh komponis yang memiliki peran penting dalam perancangannya (Dewi, 
2016). Dalam karya ini, cadenza dirancang tidak terlalu panjang dan tentu saja berisi teknik-teknik serta potongan motif-motif yang ada sebelumnya. Berikut adalah notasi kadensa dalam konserto etude.
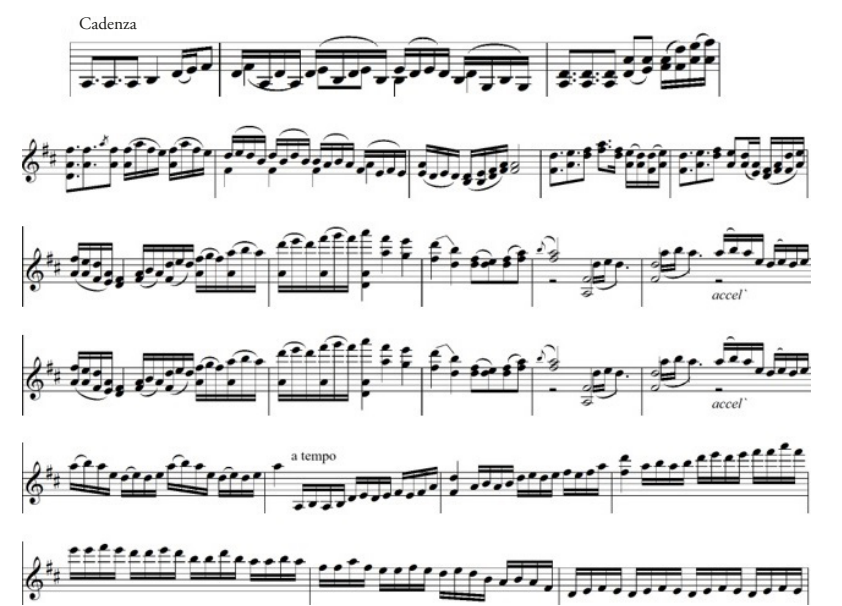

Gambar 12: Cadenza dari konserto etude.

Setelah sebuah kadensa, selanjutnya masih ada beberapa teknik yang dirancang, salah satunya adalah legato spiccato. Teknik ini banyak terdapat di berbagai buku etude seperti Kayser, Kreutzer, Dont, Paganini, dan diberbagai karya konserto biola di dunia. Berikut adalah sebuah teknik legato spiccato.

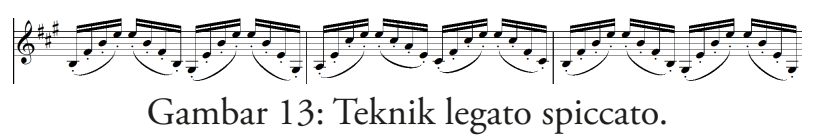

Sebagai penutup atau coda dirancang sebuah tangganada mayor pentatonik dengan memakai nada keempat dan ketujuh yang diturunkan setengah nada. Berikut adalah notasi untuk pasase penutup atau coda.

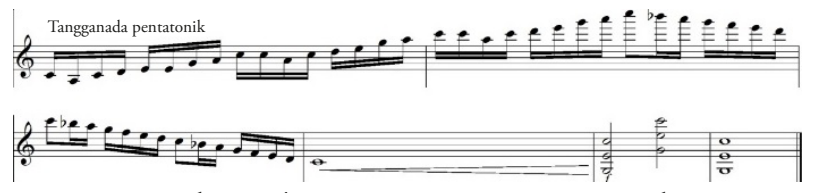

Gambar 14: Pasase penutup atau coda.

Menurut Kaestri, perancangan karya musik yang mengandung pola tangga nada diatonis dan pentatonik dapat diselaraskan sehingga rancangan tersebut relatif mampu menyesuaikan antara satu dengan yang lainnya (Kaestri, 2021). Apabila dibaca dari latar belakang sampai dengan proses dan rancangan penciptaan, ditambah lagi dengan judul karya yaitu Konserto Etude untuk Biola dan Orkestra dalam Tangganada Pentatonik Bebas, maka sesungguhnya diskripsi karya sudah terdiskripsi secara jelas. Setelah selesai merancang karya utama untuk part solo biola, selanjutnya dibuat orkestra sebagai pengiring solo biola, dimana seluruh instrumen orkestra berbunyi bersama dengan keras meminta perhatian, dan kelompok perkusi menangapi, kemudian biola solo masuk memainkan motif pertama. Berikut adalah skor orkestra sebagai pembuka sepanjang 4 birama untuk masuk solo biola dan diulang dua kali, intinya meminta perhatian penonton.

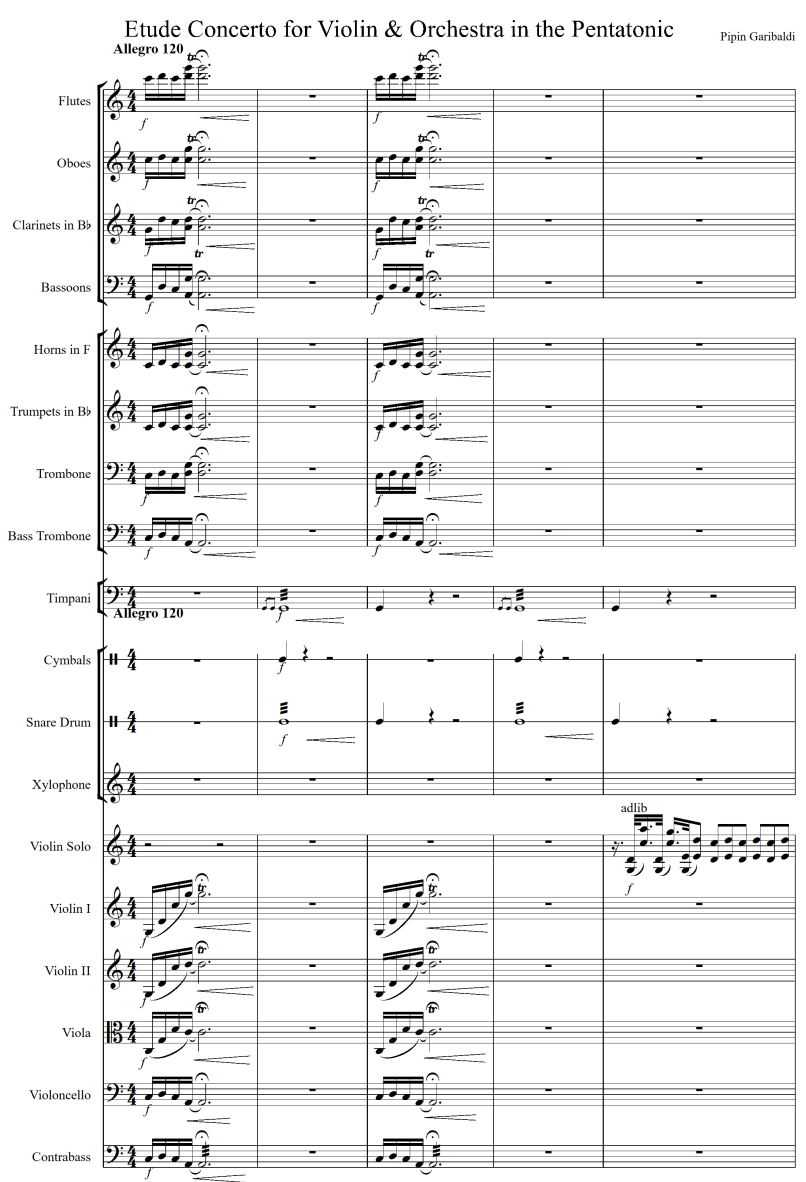

Gambar 15: Potongan skor orkestra sebagai pembuka.

Indrawan mengemukakan bahwa karya-karya konserto diasosiasikan dengan komposisi orkestra yang menampilkan atraksi solo instrumental sebagai solis. Menurutnya, bagian orkestra sulit untuk direduksi karena akan menghilangkan detil tertentu yang menjadi ciri karya tersebut (Indrawan, 2015). Namun karena tidak memungkinkan mendiskripsikan seluruh bagian orkestra, maka deskripsi difokuskan pada kelompok orkestra yang memainkan ritme lancaran. Pembelajaran terhadap musik tradisional sudah pernah ditulis oleh Irawati (2019) yaitu bahwa dalam suatu musik 
non literate terdiri dari tiga aspek yaitu pelaku, konten, dan mekanisme (Irawati, 2016; 2019), demikian pula halnya dengan konteks ruang pembelajaran kelas musik di Pendidikan formal pentingnya menghadirkan tentang gambaran kehidupan masyarakat pengguna dalam keseharian terkait dengan music yang akan diajarkan (Irawati, 2021). Demikian pula halnya dengan pembelajaran yang akan penulis lakukan dalam pembelajaran menggunakan idiom musik tradisional Jawa. Berikut adalah konten yaitu skor orkestra yang memunculkan ritme lancaran.

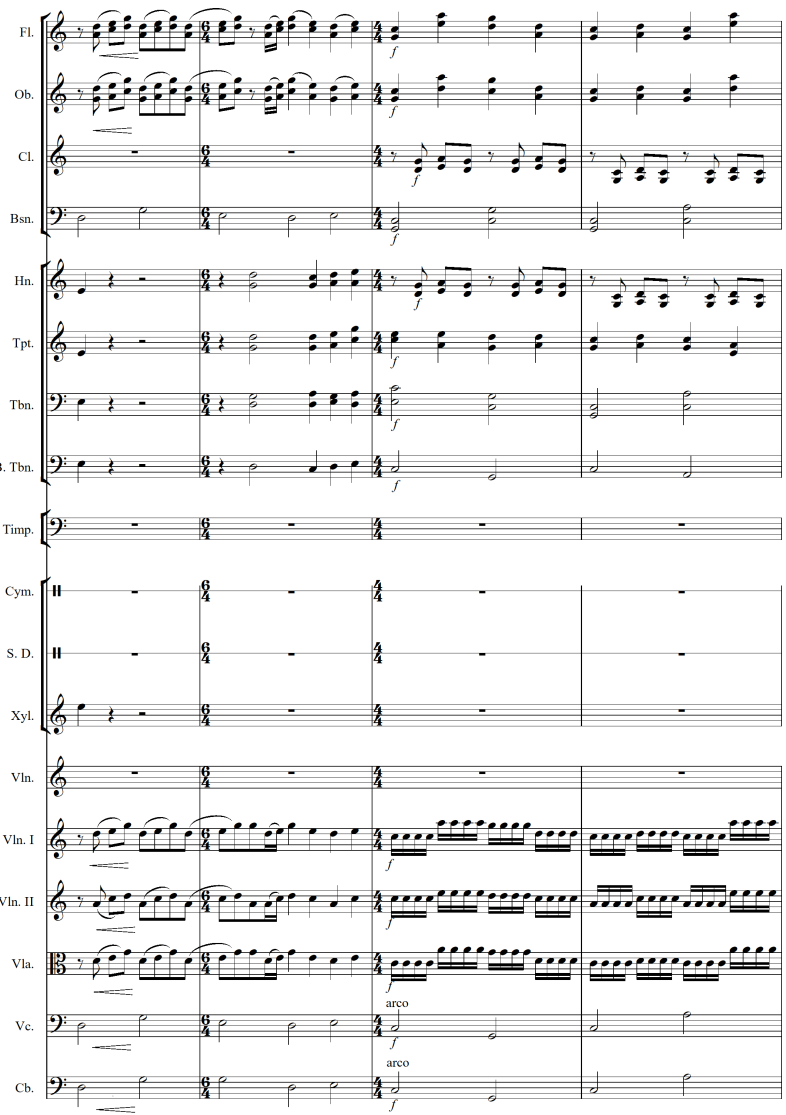

Gambar 16: Ritme lancaran.

Ritme lancaran terus dimainkan oleh flut, oboe, biola 1, 2, dan alto, sedangkan instrumen lain mengiringi, lalu masuk dalam ritme gangsaran pada kelompok gesek. Berikut adalah notasi kelompok gesek memainkan ritme gangsaran.

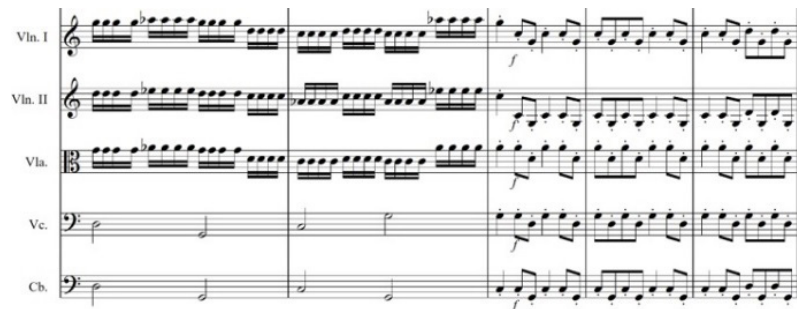

Gambar 17: Ritme gangsaran pada instrumen gesek.
Tanya jawab, sahut menyahut, saling menanggapi antara kelompok gesek dan tiup berlangsung semakin intensif. Berikut adalah notasi yang menunjukkan komunikasi antara gesek dan tiup dalam bentuk saling menanggapi.

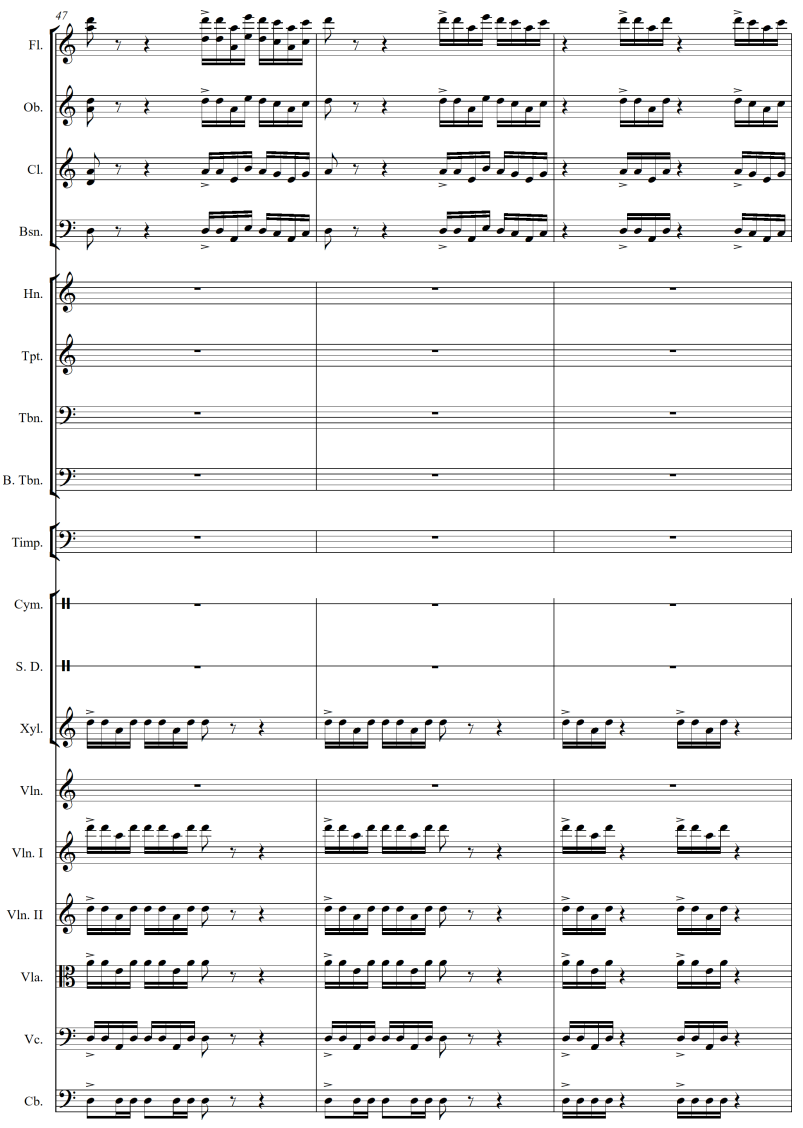

Gambar 18: Saling menanggapi antara gesek dan tiup.

Tanya jawab, sahut menyahut antara gesek dan tiup kayu semakin memuncak dengan masuknya perkusi dan tiup logam. Berikut adalah notasi kelompok tiup logam yang melengkapi sahut menyahut gesek dan tiup kayu.

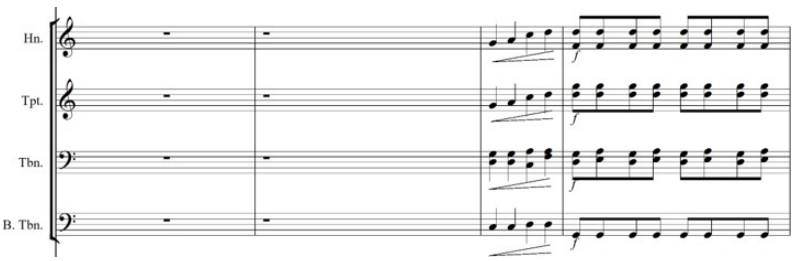

Gambar 19: Tiup logam melengkapi sahut menyahut gesek tiup dan kayu.

Puncak ketegangan kelompok gesek, tiup kayu, logam, dan perkusi dalam saling menanggapi, ternyata mengundang solo biola untuk masuk memainkan tema utama, dengan iringan celo dan bass dengan ritme gangsaran. Berikut adalah potongan notasi yang menunjukkan masuknya solo biola membawakan tema konserto (secara lengkap ada dalam skor). 


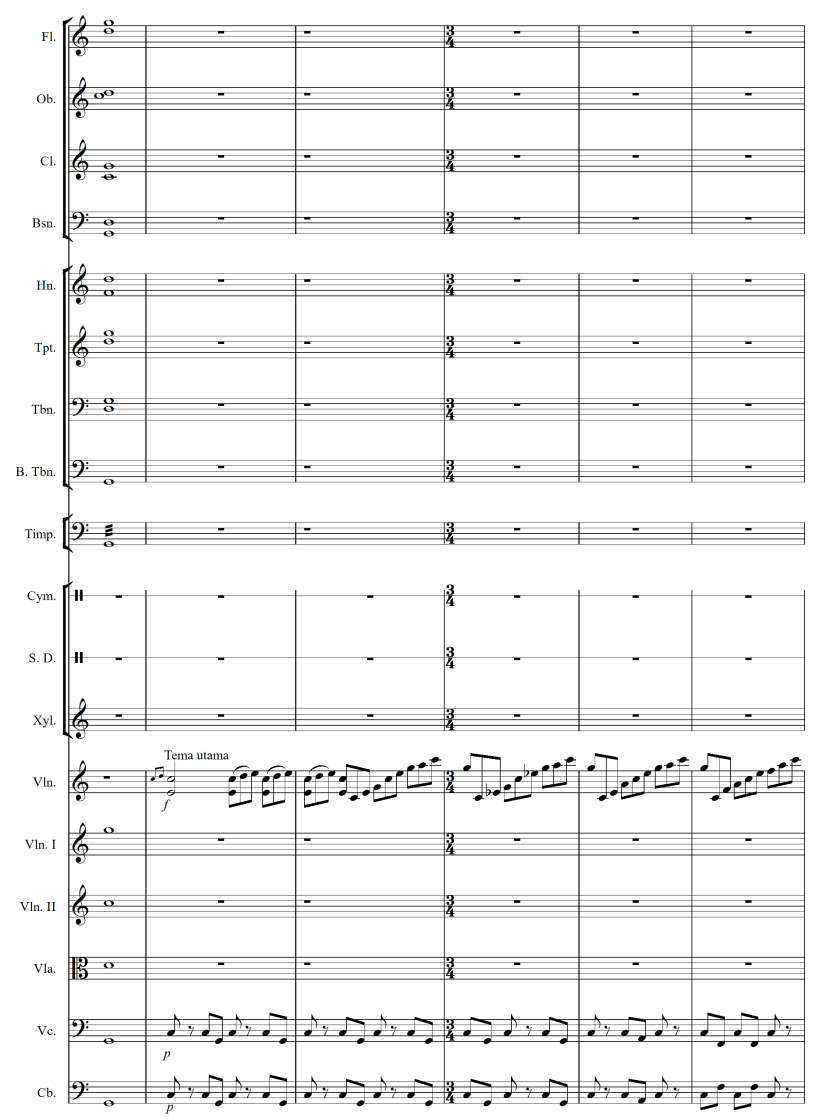

Gambar 20: Masuknya solo biola membawakan tema konserto (secara lengkap ada dalam partitur).

\section{Kesimpulan}

Berdasarkan rumusan penciptaan, maka dapat disimpulkan bahwa penciptaan konserto biola dengan bentuk bebas, dalam satu gerakan, ternyata lebih leluasa untuk berkreasi dalam menuangkan ide-ide yang diinginkan, semua dapat dimasukkan dalam bagian cepat-lambat-cepat (allegro, andante, allegro), leluasa menggunakan pergantian tanda sukat, modulasi, harmoni, dan sebagainya, karena tidak terikat aturan-aturan bentuk dan struktur yang sudah baku dalam musik klasik Barat.

Penciptaaan konserto biola yang sekaligus berisi etude atau teknik-teknik biola dapat disimpulkan bahwasanya, utamanya harus memainkan, mengamati, mencermati berbagai macam etude, dan keterampilan pelajar atau pemain biola yang dituju.

Pemakaian ritme atau irama lancaran, gangsaran, tangganada pentatonik (anhemitonik) dipakai sebagai pendukung karya yang lebih bernuansa Timur (Jawa) dibanding suasana Barat ternyata sangat baik hasilnya, tetapi karena menggunakan tangganada pentatonik anhemitonik, maka konserto ini apabila didengarkan lebih terasa seperti konserto musik Mandarin.

Dengan adanya perubahan kurikulum Prodi Musik tahun 2021, dimana instrumen violin yang semula terdiri dari Menengah 1, 2, 3, sampai dengan Lanjut 1, 2, 3, menjadi hanya studi instrumen (violin) 1, 2, 3, maka konserto etude ini menjadi cukup sulit bagi pembelajaran mahasiswa violin 3 .

\section{Kepustakaan}

Adler, S. (2002). The Study of Orchestration. In WW Norton \& Company, Inc., Copyright.

Brindle, R. S. (1986). Musical composition. Oxford University Press.

Cole, W. (1979). The Form of Music. The Associated Board of the Royal School of Music.

de Fretes, D., Pramuditya, P., Lundito, F. J., \& Kusumaningrum, M. R. M. (n.d.). Pemetaan Teknik Double-Stops Pada Violin Concerto No. 2 Anatoly Komarowsky. Grenek: Jurnal Seni Musik, 10(2), 81-91.

Dewi, M. O. R. (2016). Analisis Teknik Komposisi Musik "Variation on Theme of Sepasang Mata Bola” Karya Jazeed Djamin. Resital: Jurnal Seni Pertunjukan (Journal of Performing Arts), 17(2), 98-117.

Irawati, Eli. (2019). Transmission of Kelentangan Music Among the Dayak Benuaq of East Kalimantan in Indonesia. Malaysian Journal of Music, 8 (1), 108-121. https://doi.org/10. 37134/mjm.vol8.7.2019

Irawati, Eli. (2021). The Transmission of Resilience Learning in the Context of Formal Education an Ethnomusicological Review. Linguistics and Culture Review, 5 (S3), 1040-1053. https:// doi.org/10.21744/lingcure.v5nS3.1664

Indrawan, A. (2015). Adaptasi Konserto pada Ensambel Gitar sebagai Upaya Pengayaan Bahan Ajar Matakuliah Ensambel. Resital: Jurnal Seni Pertunjukan, 16(2), 95-103. https://doi.org/10.24821/resital.v16i2. 1509

Kaestri, V. Y. (2021). Perancangan Aransemen Lagu Suwe Ora Jamu dan Cublak-Cublak Suweng Ditinjau dari Perspektif Ilmu Harmoni Dasar. 
Resital: Jurnal Seni Pertunjukan (Journal of Performing Arts), 22(1), 36-47.

Keller. (2016). Program Notes of the Oklahoma City Philharmonic: "The Butterfly Lovers Concerto for Violin and Orchestra (Violin Concerto Liang Shanbo dan Zhu Yingtai), karya Chen Gang, dan He Zhan Hao.

Machlis, J. (1963). The Enjoyment of Music: An Introduction to Perspective Listening. W.W. Norton \& Company Inc.

Mack, D. (1995). Sejarah Musik Jilid 3 (I). Pusat Musik Liturgi.
McNeill, R. J. (1998). Sejarah Musik 1. PT BPK Gunung Mulia.

Palmer, K. (1952). Teach Yourself to Compose Music. English Universities Press.

Sadie, S. (2002). The New Grove Dictionary of Music and Musicians. London: Macmillan.

Stein, L. (1962). Structure and style: the study and analysis of musical forms. Summy-Birchard Company.

Westrup, J. A., Harrison, F. L., \& Wilson, C. (1976). Collins Encyclopedia of Music. Harper Collins Publishers. 